\title{
Breaking Up Is Hard to Do: Allocating Fees from the Unfinished Business of a Professional Corporation
}

\author{
Christopher C. Wang †
}

Today, lawyer mobility is the norm rather than the exception. ${ }^{1}$ No longer can a freshly minted lawyer expect to stay with one law firm from law school graduation until election to partnership. This increased mobility is paralleled by a rapid rise in the number of law firm breakups. ${ }^{2}$ While many attorneys who practice together reach an amicable agreement to go their separate ways, the acrimony involved in some breakups is legendary. In one breakup, departing partners drove up in a van in the dead of night and swiped away client files. ${ }^{3}$ In another, a lawyer physically attacked his partner and threw him out of their office. ${ }^{4}$ In addition to engendering bitter feelings among the parties involved, breakups frequently result in disputes that cost hundreds of thousands of dollars in legal fees and drag on for decades. ${ }^{5}$

The most significant of these legal disputes involves the division of fees and responsibilities from the firm's ongoing business between the firm's continuing members and those who withdraw. Out of either carelessness or a simple unwillingness to plan for the worst, law firms often fail to adopt in advance a written agreement spelling out the division of this "unfinished business," leaving courts to allocate the fees and responsibilities. Courts

$\dagger$ B.A. 1995, Yale University; J.D. Candidate 1998, The University of Chicago.

1 See generally Robert W. Hillman, Hillman on Lawyer Mobility: The Law and Ethics of Partner Withdrawals and Law Firm Breakups § 1.1 at 1:1-8 (Little, Brown 1994). Law firms, understandably concerned about this trend, have attempted to respond. See, for example, David Segal, Law Firms Court Own Attorneys; Treatment Improved in Bid to Cut Defections, Wash Post A1, A1 \& A8 (Dec 30, 1996) (describing efforts by large Washington, D.C. law firms to prevent associate defections).

2 Breakups are not exclusively the domain of any particular type of firm. See, for example, Amy Stevens and Edward Felsenthal, Mudge Rose to Close by End of the Year, Wall St J B4 (Oct 3, 1995) (describing close of 126-year-old New York law firm Mudge Rose Guthrie Alexander \& Ferdon); Edward Felsenthal, Hard to Do: The Messiest Divorce That Jacoby \& Meyers Ever Handled: Its Own, Wall St J A1 (Jan 23, 1996) (describing breakup of Jacoby \& Meyers, the Los Angeles law firm that pioneered the controversial use of TV advertising and fixed fees for law firms).

${ }^{3}$ Laurel S. Terry, Ethical Pitfalls and Malpractice Consequences of Law Firm Breakups, 61 Temple L Rev 1055, 1058 (1988).

Id.

${ }^{5}$ Id at 1059. 
have increasingly relied on the Uniform Partnership Act ("UPA") to aid them in this task. The UPA provides that a partnership is automatically dissolved when one partner leaves the firm. ${ }^{7}$ Following dissolution, all partners have a fiduciary duty ${ }^{8}$ to wind up the unfinished business of the firm ${ }^{9}$ and to divide the resulting fees with their former colleagues on a pro rata basis. ${ }^{10}$ Through-

6 Uniform Partnership Act (1914), 6 ULA 125 (West 1995). By 1990, the UPA had been adopted in forty-nine states, with few variations among the enacted statutes. Hillman, Lawyer Mobility $\S 4.1$ at 4:2 (cited in note 1). Many of these jurisdictions have applied the UPA to law firm dissolutions. See, for example, Schrempp and Salerno $v$ Gross, $247 \mathrm{Neb} 685,529$ NW2d 764, 770-72 (1995); Gull v Van Epps, 185 Wis 2d 609, 517 NW2d 531, 533 (Wis Ct App 1994); Kirsch v Leventhal, 181 AD2d 222, 586 NYS2d 330, 332-33 (NY App Div 1992); Ellerby $v$ Spiezer, 138 Ill App 3d 77, 485 NE2d 413, 415-17 (1985); Jewel $v$ Boxer, 156 Cal App 3d 171, 203 Cal Rptr 13, 16-19 (1984); Resnick v Kaplan, 49 Md App 499, 434 A2d 582, 586-88 (Md Ct Spec App 1981). Several commentators, however, have argued that the UPA dissolution and windup provisions are inappropriate for a law partnership. See, for example, Mark I. Weinstein, The Revised Uniform Partnership Act: An Analysis of Its Impact on the Relationship of Law Firm Dissolution, Contingent Fee Cases and the No Compensation Rule, 33 Duquesne L Rev 857, 872 (1995).

7 "The dissolution of a partnership is the change in the relation of the partners caused by any partner ceasing to be associated in the carrying on as distinguished from the winding up of the business." UPA § 29, 6 ULA 752 (cited in note 6).

The Uniform Partnership Act (1994), 6 ULA 1 (West 1995), also known as the Revised Uniform Partnership Act ("RUPA"), provides for an entity theory of partnership. The departure of a partner ("dissociation") no longer automatically dissolves the partnership, but can result in a winding up of the partnership business or a buyout of the departing partner, depending on the circumstances. See Donald J. Weidner and John W. Larson, The Revised Uniform Partnership Act: The Reporters' Overview, 49 Bus Law 1, 6-13 (1993). The RUPA has been adopted in Alabama, Arizona, California, Connecticut, Florida, Montana, New Mexico, North Dakota, Texas, Virginia, and West Virginia. RUPA, 6 ULA 1 (West Supp 1997). The RUPA provides that a partnership at will is still dissolved when it is notified of a partner's express will to withdraw as a partner. RUPA $\$ 801(1), 6$ ULA 92. Almost all law partnerships are terminable at will. Robert W. Hillman, Hillman on Lawyer Mobility: The Law and Ethics of Partner Withdrawals and Law Firm Breakups $\S 4.6 .3$ at 4:67 (Aspen Law \& Bus 1997). Moreover, the process of winding up a partnership under the RUPA resembles winding up a partnership under the UPA. Id $\$ 4.7$ at 4:80. Therefore, allocating fees from the unfinished business of a law partnership is likely to change little under the RUPA.

8 UPA $\S 21$ is titled "Partner Accountable as a Fiduciary." It provides, in relevant part:

Every partner must account to the partnership for any benefit, and hold as trustee for it any profits derived by him without the consent of the other partners from any transaction connected with the formation, conduct, or liquidation of the partnership or from any use by him of its property.

UPA § 21(1), 6 ULA 608 (cited in note 6). The partners are fiduciaries among themselves and owe each other fiduciary duties of utmost good faith, fairness, and loyalty. Alan $R$. Bromberg and Larry E. Ribstein, 2 Bromberg and Ribstein on Partnership $\$ 6.07$ at 6:6768 (Little, Brown 1996). For a good general discussion of partners' fiduciary duties, see id $\S 6.07$ at 6:67-73.

9 "On dissolution the partnership is not terminated, but continues until the winding up of partnership affairs is completed." UPA § 30, 6 ULA 756 (cited in note 6). See generally Bromberg and Ribstein, 2 Partnership $\$ 7.08$ at 7:73-88 (cited in note 8).

${ }^{10}$ "No partner is entitled to remuneration for acting in the partnership business, ex- 
out the windup period, partners have a fiduciary duty to act in good faith toward one another. ${ }^{11}$ Only upon completion of the unfinished business is the partnership, and thus the fiduciary duty between partners, terminated. ${ }^{12}$

Not all law firms, however, are organized as partnerships. For a law firm organized as a professional corporation-an entity that possesses qualities of both a partnership and a corporation-the problem of dividing "unfinished business" among the attorney-shareholders is more complex. This complexity exists because courts disagree on whether to apply the principles of partnership law or corporate law to the problems that arise from the withdrawal of lawyers from a professional corporation. In Fox $v$ Abrams, ${ }^{13}$ the Court of Appeal of California applied the unfinished business rule of partnership law to a professional corporation. A majority of courts have followed the rule established in Fox. Positive attributes of this approach include the consistent treatment of lawyers across organizational forms and the ease of judicial administration. Nevertheless, the Fox rule is inconsistent with significant attributes of the professional corporation, most notably its continued existence following a shareholder withdrawal.

A minority of courts apply corporate law standards to the withdrawal of an attorney-shareholder from a professional corporation. ${ }^{14}$ While most state professional corporation statutes do not specifically provide for the quick termination of a shareholder's interest upon his withdrawal, ${ }^{15}$ an analogy to general

cept that a surviving partner is entitled to reasonable compensation for his services in winding up the partnership affairs." UPA $\S 18(f), 6$ ULA 526 (cited in note 6). Postdissolution income is distributed to former partners of the old firm in accordance with their percentage interests in the former partnership. The former partners are entitled to "reasonable overhead expenses" attributable to the production of such income. Jewel, 203 Cal Rptr at 19. For a good explanation of the "unfinished business rule," see J. William Callison, Partnership Law Issues in the Break-up and Dissolution of Law Firms, 21 Colo Law 409, 412-14 (1992).

${ }^{11}$ Bromberg and Ribstein, 2 Partnership $\$ 6.07$ at 6:72-73 (cited in note 8), citing UPA $\$ \S 21(1), 30$. See also Jewel, $203 \mathrm{Cal}$ Rptr at 19.

12 Bromberg and Ribstein, 2 Partnership $\$ 7.01$ at 7:6 (cited in note 8).

${ }^{23} 163$ Cal App 3d 610, 210 Cal Rptr 260, 265-66 (1985). As of yet, there is no case law on the application of RUPA to attorney-shareholder withdrawals from professional corporations. The application of the RUPA is likely to be similar to the application of the UPA. See note 7 .

14 See, for example, Langhoff $v$ Michael E. Marr, 81 Md App 438, 568 A2d 844, 855-56 (Md Ct Spec App 1990); Melby v O'Melia, 93 Wis 2d 51, 286 NW2d 373, 374 (Wis Ct App 1979).

${ }^{15}$ Hillman, Lawyer Mobility $\$ 6.5 .1$ at 6:22-23 (cited in note 1). Hillman infers this requirement from various statutes common to many states, such as mandates for a prompt transfer of shares to the corporation following a withdrawal, restrictions on ownership of stock in more than one professional corporation, and denials of voting rights following in- 
corporate law is helpful. General corporate law provides for the termination of a shareholder's interest in a corporation upon the sale of his shares ${ }^{16}$ and suggests that any fiduciary duty to wind up unfinished business in a professional corporation would end upon the sale of shares. ${ }^{17}$

A case following the minority approach confirms this intuition. According to Langhoff v Michael E. Marr ("Langhoff $\left.I^{\prime}\right),{ }^{18}$ under corporate law an employee of a professional corporation is permitted to compete with the corporation following the termination of the employment relationship. This standard is clearly inconsistent with the fiduciary duty of all attorney-shareholders in a professional corporation to complete unfinished business upon an attorney-shareholder withdrawal and to divide the resulting fees pro rata. Instead, under corporate law, withdrawing attorney-shareholders have no duty to complete the professional corporation's business for the benefit of the continuing attorneyshareholders, and vice versa. Given this termination of duty, courts should allocate fees from unfinished business under the corporate standard on a quantum meruit basis to reflect the reasonable value of the work done by both sides before the withdrawal. This corporate law standard should also apply where the professional corporation has refused to purchase the shares of the departing attorney and the court has denied the attorney's request to force the professional corporation to do so. The professional corporation's refusal to repurchase is consistent with corporate law approaches. ${ }^{19}$ Thus, corporate law approaches should also apply to the allocation of fees. And under Langhoff $I$, all that

voluntary resignation. Id § 6.5.1 at 6:21-22.

${ }^{16}$ Id $\&$ 6.5.1 at 6:23.

${ }^{17}$ Hillman declares that "[t]he concept of completing unfinished business during a winding-up period is antithetical to the corporate model calling for a termination of shareholder status upon the surrender of shares.” Id § 6.5.1 at 6:23. He also claims, however, that simply applying corporate law cannot be the answer because "under those statutes that provide for joint and several liability, the simple act of withdrawal may not in and of itself eliminate the risk of liabilities later asserted." Id. Given the context of this statement, Hillman may be rejecting the application of corporate law only insofar as it concerns liability.

${ }^{18} 81$ Md App 438, 568 A2d 844, 853 (Md Ct Spec App 1990).

${ }^{19}$ Courts will generally not force a close corporation to redeem a minority shareholder's shares through involuntary dissolution absent a shareholder deadlock or illegal, oppressive, or fraudulent conduct by the majority. See Frank H. Easterbrook and Daniel R. Fischel, The Economic Structure of Corporate Law 239 (Harvard 1991). This rule may not hold for professional corporations engaged in the practice of law. See Edward A. Adams, Judge Orders Dissolution of Law Firm: Standard is Lower Level of Conflict Than Usual Under Business Corporation Law, NY L J 1, 1 (Feb 15, 1996) (" $[\mathrm{A}]$ lower level of conflict can require dissolution of a law firm because courts must take into account the consequences of that dissension upon the firm's clients and the public trust in the legal system."'). 
is required for corporate law to apply is that the employment relationship be terminated.

Comparing the majority and minority approaches, a pattern emerges in whether courts apply partnership or corporate law to an attorney-shareholder withdrawal from a professional corporation. Courts, recognizing the professional corporation's continuity of life, have implicitly distinguished attorney departures where the professional corporation has dissolved from attorney departures where the professional corporation continues to exist. After categorizing the withdrawal in this manner, courts have applied partnership law to professional corporations that dissolve and corporate law to those that survive. Courts have deviated from this general rule, however, to account for extenuating circumstances pertaining to the withdrawal. Unfortunately, these deviations create an ad hoc "totality of the circumstances" test that requires courts to engage in extensive factfinding and fails to provide notice both to the parties involved and to future litigants.

This Comment argues that courts should explicitly acknowledge the implicit and sensible categorization of attorneyshareholder withdrawals based on whether the corporation dissolves (applying partnership law) or survives (applying corporate law). They should also abandon attempts to account for extenuating circumstances when deciding what law to apply to these withdrawals. Instead, they should rely solely on this bright line standard. Such a standard is more faithful than the "extenuating circumstances" approach to both the structure of the professional corporation and the applicable state corporate law statutes. It is also easier for courts to administer. Furthermore, this bright line standard will greatly benefit attorney-shareholders practicing in professional corporations insofar as they will have fair notice of the governing rule. They will be able to adjust their behavior according to whether they desire partnership or corporate law treatment. If they want partnership law treatment, they will dissolve the professional corporation; if they want corporate law treatment, they will not.

Part I of this Comment provides an overview of the history of law firm incorporation and the structure of the professional corporation. Part II examines the existing case law on the withdrawal of attorney-shareholders from a professional corporation. Part III asserts that courts' treatment of attorney-shareholder withdrawals is based upon their implicit categorization of the withdrawal. It argues that all deviations from this rule are either reconcilable with the rule or incorrect interpretations of the partnership law principles from which the rule was derived. Part 
IV argues that courts should explicitly acknowledge their use of the professional corporation's future in determining what law to apply. It then proposes that courts rely solely on a default rule under which partnership law applies to an attorney-shareholder withdrawal only where the withdrawal is concurrent with the dissolution of the professional corporation.

\section{The PROFESSIONAL CoRPORATION}

\section{A. History of the Professional Corporation}

Prior to 1960 , no state allowed professionals, including lawyers, to incorporate. ${ }^{20}$ This denial of the incorporation option prevented professionals from availing themselves of limited liability and significant tax advantages, including the opportunity to establish pension plans offering greater benefits than those available to partnerships. ${ }^{21}$ Resistance to allowing law firm incorporation in particular rested upon two major concerns: first, the possibility that the corporation itself might interfere with the professional relationship between each client and the attorney handling his case; and second, the possibility that lawyers could avoid malpractice liability. ${ }^{22}$ By intense lobbying in the 1960 s and 1970 s, however, lawyers and other professionals succeeded in assuaging these concerns. ${ }^{23}$ Today, every jurisdiction allows lawyers to incorporate and form "professional corporations" or "professional associations." ${ }^{24}$ The tax benefits of incorporation decreased significantly with tax reform in the early $1980 \mathrm{~s},{ }^{25}$ and to-

20 Thomas A. Denker, Note, Lawyers and Limited Liability for Arizona's Professionals: Deliverance or Damnation?, 37 Ariz L Rev 355, 358 (1995); Steven E. Kalish, Lawyer Liability and Incorporation of the Law Firm: A Compromise Model Providing LawyerOwners with Limited Liability and Imposing Broad Vicarious Liability on Some LawyerEmployees, 29 Ariz L Rev 563, 563 (1987).

${ }^{21}$ Hillman, Lawyer Mobility $\$ 6.1$ at 6:2 (cited in note 1). See also William A. Gregory and Thomas R. Hurst, Cases and Materials on Agency and Partnership 676 (West 1994).

${ }^{2}$ Denker, Note, 37 Ariz L Rev at 358 (cited in note 20).

${ }^{23}$ Id.

24 The classification of a professional corporation or association for purposes of taxation is determined according to the standards of Internal Revenue Regulations. See Treas Reg $\$ \S 301.7701-2,301.7701-3,301.7701-4$. The label applied to the entity under state law is irrelevant. Harold G. Reuschlein and William A. Gregory, The Law of Agency and Partnership § 301 at 504 (West 2d ed 1990).

${ }^{25}$ The passage of the Economic Recovery Tax Act of 1981, Pub L No 97-34, 95 Stat 172, and the Tax Equity and Fiscal Responsibility Act of 1982, Pub L No 97-248, 96 Stat 324 , "essentially equalized the tax treatment of corporations and non-corporate business organizations." Denker, Note, 37 Ariz L Rev at 358-59 (cited in note 20). See also David Paas, Professional Corporations and Attorney-Shareholders: The Decline of Limited Liability, $11 \mathrm{~J}$ Corp L 371, 374 (1986) ("[R]ecent changes in the tax laws have removed most, if not all, of the tax incentives for the creation of professional corporations. If there is any reason left to incorporate a professional practice, it cannot be a tax reason."). 
day the primary advantage of the professional corporation is the limited liability it affords to its members. ${ }^{26}$

\section{B. Structure of the Professional Corporation}

A professional corporation possesses qualities of both a partnership and a corporation. From a functional standpoint, a law firm incorporated as a professional corporation is fundamentally the same as a partnership. The shareholders of a professional corporation own the business and are generally compensated like partners in that they receive an annual salary and a share of profits and losses. ${ }^{27}$ The shareholders also conduct themselves as partners both in their relations with each other and in their relations with their clients. ${ }^{28}$ In other contexts, these similarities have led courts to treat professional corporation shareholders more like partners than like employees of the corporation. ${ }^{29}$ Many courts have also held that, from a purposive standpoint, the professional corporation is more like a partnership than like a corporation because a major motivating force behind lawyers' use of the professional corporation was the tax benefits it pro-

${ }^{25}$ Paas, $11 \mathrm{~J}$ Corp $\mathrm{L}$ at 374 (cited in note 25). The scope of limited liability for attorneys practicing in professional corporations varies considerably across states. Statutes range from ones that hold lawyers responsible only for their own acts, errors, or omissions, to statutes that hold all lawyers jointly and severally liable for claims arising from the provision of legal services unless the firm maintains an adequate amount of liability insurance. See Hillman, Lawyer Mobility $\$ 6.3$ at 6:8-11 (cited in note 1). Because courts have traditionally exercised regulatory power over attorney conduct, id $\S 6.4$ at $6: 12$, there is a tension between judicial oversight and state statutes that limit attorney liability. Courts have been both aggressive in expanding attorney liability beyond the state statute, see id $\S 6.4 .1$ at $6: 14-17$, and deferential to the state statute, see id $\S 6.4 .2$ at $6: 17-$ 18.

The limited liability protection afforded to attorneys by professional corporations may soon be a moot point, however, with the advent in the past decade of limited liability companies ("LLCs") and limited liability partnerships ("LLPs") as law firm structures. For a discussion of the history of these two organizational forms and their attraction for lawyers, see N. Scott Murphy, Note, It's Nothing Personal: The Public Costs of Limited Liability Law Partnerships, 71 Ind L J 201, 206-14 (1995).

${ }^{27}$ John Narducci, Note, The Application of Antidiscrimination Statutes to Shareholders of Professional Corporations: Forcing Fellow Shareholders Out of the Club, 55 Fordham L Rev 839, 851-53 (1987).

${ }^{23}$ Id at 853-54.

${ }^{2}$ See, for example, Fountain v Metcalf, Zima \& Company, PA, 925 F2d 1398, 1400 (11th Cir 1991) (reasoning that the shareholders of a professional corporation should be treated like partners for purposes of Title VII actions); EEOC v Dowd \& Dowd, Ltd, 736 F2d 1177, 1178-79 (7th Cir 1984) (same). See also Narducci, Note, 55 Fordham L Rev at 851-59 (cited in note 27) (arguing that under an economic realities test, shareholders of a professional corporation are not employees for purposes of standing under the Age Discrimination and Employment Act and Title VII). But see Jones $v$ Baskin, Flaherty, Elliot and Mannino, PC, 670 F Supp 597, 602 (W D Pa 1987) (holding that where an attorneyshareholder of a professional corporation has little control over management of the corporation, he is an employee for ADEA purposes). 
vided. ${ }^{30}$ Whether these holdings are correct today is open to dispute, given that the disparity between the tax treatment of partnerships and professional corporations has disappeared. Additionally, while favorable tax treatment may have been the driving force behind choosing formation as a professional corporation in the past, these holdings overlook the continuing importance of a professional corporation's limited liability.

A professional corporation also possesses significant corporate attributes. The Treasury Regulations provide that the following six factors characterize a corporation: (1) associates; (2) an objective to carry on business and divide the gains; (3) continuity of life; (4) centralization of management; (5) limited liability; and (6) free transferability of interests. ${ }^{31}$ A professional corporation possesses most or all of these attributes. The existence of these common traits led one scholar to argue that "the notion that shareholders of an incorporated law firm are 'partners' except for tax purposes does not comport with the corporate characteristics assigned their firms by state law. ${ }^{n 2}$ The most significant of these corporate characteristics is continuity of life. A partnership technically dissolves when one partner leaves. By contrast, a professional corporation does not dissolve upon the departure of a shareholder. The dissolution of a professional corporation is subject to statutory provisions that are applicable to corporations generally. ${ }^{33}$ These statutes suggest that in order for the profes-

${ }^{30}$ See Fox, $210 \mathrm{Cal}$ Rptr at 265 (' $\mathrm{It}$ is well-known that the primary purpose of the law permitting professionals to incorporate was to allow them to take advantage of various tax benefits available to corporate employers and employees."); Vinall DDS, PC $v$ Hoffman, 133 Ariz 322, 651 P2d 850, 851-52 (Ariz 1982) ("[T] ating the professional corporation was to permit professionals to take advantage of various federal tax provisions available to a corporation and its employees but not available to self-employed persons or partnerships."). See also Petition of New Hampshire Bar Association, $110 \mathrm{NH} \mathrm{356,266} \mathrm{A2d} \mathrm{853,} 854$ (1970) (explaining the tax benefits of incorporation); In the Matter of Rhode Island Bar Association, 106 RI 752, 263 A2d 692, 695 (1970) (same); In the Matter of the Florida Bar, 133 S2d 554, 555 (Fla 1961) (same).

${ }^{31}$ Treas Reg § 301.7701-2(a)(1) (amended 1983).

${ }^{32}$ Hillman, Lawyer Mobility $\S 6.2$ at 6:6 (cited in note 1). See also Easterbrook and Fischel, Economic Structure of Corporate Law at 248-49 (cited in note 19) (arguing that corporate law should apply to participants in closely held corporations unless they explicitly contract for partnership-like rules because it is unrealistic to assume that they were only motivated by the tax effects of incorporation).

${ }^{33}$ Richard S. Green, Firm Dissolutions: Causes and Effects, 475 PLI/Comm 167, 173 (1988). See also Model Stat Close Corp Supp § 2(b) (1984) (amended 1994) ("This supplement applies to a professional corporation organized under the [Model] Professional Corporation Supplement."); Model Prof Corp Supp § 2 (1984) (amended 1994) ("The [Model] Business Corporation Act applies to professional corporations . . . to the extent not inconsistent with the provisions of this Supplement."). 
sional corporation to dissolve, its shareholders must expressly intend its dissolution. ${ }^{34}$

II. SETTLING RIGHTS AND LIABILITIES OF ATTORNEYS IN A PROFESSIONAL CORPORATION AFTER THE WITHDRAWAL OF AN ATTORNEY-SHAREHOLDER

A. Majority View: Application of Partnership Law to AttorneyShareholder Withdrawals

Most courts apply partnership law in allocating the unfinished business and resulting fees of a professional corporation upon an attorney-shareholder withdrawal. This view relies on the practical similarities between law corporations and law partnerships and on the problem of opportunistic behavior by attorneys leaving professional corporations.

\section{Fox $v$ Abrams.}

The majority view was first articulated in Fox $v$ Abrams..$^{35}$ In this case, four attorneys practiced together in a professional corporation. Their relationship soured, and three of the attorneys left to form a new corporation. The one remaining attorney then changed the name of the original corporation to reflect these changes. ${ }^{36}$ The parties had a "buy-sell agreement" providing for the buyout of a withdrawing attorney-shareholder's interest in the professional corporation. The lower court held that this buysell agreement entitled the three withdrawing attorneys to a pro rata share (reflective of former ownership interests) of the fees received by the remaining attorney for work in progress as of their resignation. The court, however, granted no similar right to the remaining attorney for fees received by his departing colleagues upon their completion of cases pending at the time of their withdrawal. Instead, Abrams, the sole remaining attorney, was entitled only to quantum meruit for the reasonable value of any services that he performed on those cases prior to the resignations. $^{37}$

\footnotetext{
${ }^{34}$ See Model Bus Corp Act $\S$ 14.03-14.07 (1984) (amended 1994) (explaining procedures by which shareholders dissolve a corporation); Model Stat Close Corp Supp § 33(a) (explaining shareholders' option to dissolve close corporation).

${ }_{35} 163$ Cal App 3d 610, 210 Cal Rptr 260 (1985).

${ }^{36}$ Although the court seems to take it as given that the original professional corporation broke up, see Fox, $210 \mathrm{Cal}$ Rptr at 262, there is nothing in the decision stating that the shareholders formally dissolved it.

${ }^{37}$ Id.
} 
The Court of Appeal of California reversed the lower court's judgment and applied the "unfinished business" rule from partnership law. The court held that all work in progress on the date of the resignations was unfinished business of the former firm. Thus, all the attorneys were entitled to share in the fees from this work in proportion to their ownership interests in the former firm. ${ }^{38}$ The court further held that all present and former shareholders possessed a fiduciary duty to complete this unfinished business for no extra compensation. ${ }^{39}$ In reaching its decision, the court declared:

The rule prevents partners from competing for the most remunerative cases during the life of the partnership in anticipation that they might retain those cases should the partnership dissolve. It also discourages former partners from scrambling to take physical possession of files and seeking personal gain by soliciting a firm's existing clients upon dissolution. ${ }^{40}$

The court further justified extending partnership law to a professional corporation by noting that the primary purpose of allowing attorneys to incorporate was for tax purposes. The court held that, as tax concerns were not at issue in the case at hand, attorneys practicing in a law corporation owed each other fiduciary duties very similar to those law partners owe each other. ${ }^{41}$

2. The persuasive authority of Fox in allocating the unfinished business of professional corporations.

Since Fox, several courts have applied partnership law to allocate the professional corporation's unfinished business upon dissolution. ${ }^{42}$ In Rothman $v$ Dolin, ${ }^{43}$ the two attorneyshareholders of Dolin \& Rothman, a professional corporation, agreed to a dissolution. When a post-dissolution dispute arose over the distribution of fees from work in progress at the time of dissolution, the Court of Appeal of California affirmed the trial court's application of partnership law to the unfinished business. ${ }^{44}$ Similarly, in Sufrin $v$ Hosier,${ }^{45}$ in which a professional

${ }^{33}$ Id at 263.

39 Id at 265.

${ }^{40}$ Id at 265, quoting Jewel, 203 Cal Rptr at 18.

${ }^{11}$ Fox, $210 \mathrm{Cal}$ Rptr at 265-66.

12 These findings do not directly follow Fox. They appear to qualify the Fox holding by applying it to withdrawal concurrent with the dissolution of a professional corporation. See note 81 .

20 Cal App 4th 755, 24 Cal Rptr 2d 571, 571 (1993).

4 Id at 573 . 
corporation dissolved after one of its two attorney-shareholders resigned, the United States District Court for the Northern District of Illinois held that work in progress at the time of the dissolution was unfinished business and that the fees derived from such work should be divided according to a UPA formula. ${ }^{46}$

In Sullivan, Bodney \& Hammond $v$ Bodney ("Sullivan I"), a Kansas court that followed Fox applied partnership law to allocate the professional corporation's unfinished business when it was clear that the attorney-shareholders intended to dissolve the professional corporation but did not go through the formal dissolution process. An analogy to contract law provides support for this conclusion; in contract law, it is generally accepted that the parties' intentions to enter into an agreement are manifested by their actions. ${ }^{48}$ Thus, when parties reach a preliminary agreement with open terms but cannot agree on those terms, "the parties are bound by their original agreement and the other matters are governed by whatever terms a court will supply." ${ }^{\$ 9}$ In Sullivan $I$, the three attorney-shareholders fixed a date upon which they would cease practicing law together as a professional corporation, but did not agree on the allocation of contingent fees. ${ }^{50}$ The Court of Appeals of Kansas reversed the trial court's finding that the attorney-shareholders were entitled to compensation in quantum meruit for the fees resulting from cases commenced prior to the dissolution date. ${ }^{51}$ Instead, the court applied partnership law to allocate these fees even though the attorneys had not complied with the formal requirements for dissolution of a professional corporation. ${ }^{2}$ The appellate court found that because the parties had clearly intended to dissolve, their actions constituted a de facto dissolution. ${ }^{53}$ The court in Sullivan I thus merely filled in the gaps of the shareholders' preliminary agreement to dissolve.

4589 F Supp 766, 767 (N D Ill 1995).

${ }^{46}$ Id at 768.

47 16 Kan App 2d 208, 820 P2d 1248, 1249 (1991).

${ }^{43}$ See E. Allan Farnsworth, 1 Farnsworth on Contracts $\$ 3.6$ at 168-69 (Little, Brown $2 d$ ed 1990).

${ }^{19}$ Id $\S 3.8 \mathrm{a}$ at $187-88$.

${ }^{50} 820 \mathrm{P} 2 \mathrm{~d}$ at 1249.

${ }^{51} \mathrm{Id}$ at 1250.

52 Id.

${ }^{63}$ Id at 1251. A subsequent case indicates that even though the parties practiced separately, Sullivan, Bodney \& Hammond continued to exist as a registered professional corporation. Sullivan, Bodney \& Hammond v Houston General Insurance Co, 2 F3d 824, 825 (8th Cir 1993) ("Sullivan II"). This fact does not change the result in the first case, which relied on a finding of "de facto dissolution." 
Fox's impact is not limited to cases in which the professional corporation has officially dissolved, either expressly or constructively. Following the holding in Fox, one court has applied partnership law to settle the unfinished business of a professional corporation even when it continues to exist. In Vowell \& Meelheim, $P C \vee$ Beddow, Erben \& Bowen, $P A,{ }^{54}$ an attorneyshareholder and two associates left a professional association to form a new firm. Before leaving the old firm, the withdrawing attorney-shareholder contacted several of his clients without the knowledge of the other attorney-shareholders. These clients agreed to switch their representation from the old firm to the new firm. The Supreme Court of Alabama agreed with the trial court's finding that the withdrawing shareholder breached his fiduciary duty as an officer, director, and shareholder of the professional association. The court also upheld the trial court's application of partnership law to the professional association's unfinished business, which included a requirement that the old firm pay a reasonable hourly rate to the new firm for the time it spent completing the cases that the withdrawing shareholder took with him. ${ }^{55}$

3. Applying partnership law in other contexts to settle the rights and responsibilities of attorney-shareholders in professional corporations.

One court has also applied partnership law to settle the rights and responsibilities of attorney-shareholders withdrawing from a professional corporation. While this case is not directly on point, it provides insight into the general mindset of courts dealing with the problems of a professional corporation breakup. In Boyd, Payne, Gates \& Farthing, PC v Payne, Gates, Farthing $\&$ Radd, $P C,{ }^{56}$ a Virginia case, four attorney-shareholders left a professional corporation to form a separate professional corporation. The original professional corporation, then consisting of the one remaining member, claimed that it was the owner of all corporate assets, including accounts receivable, unearned professional liability insurance premiums, office furniture and equipment, and fiduciary fees. The former members alleged in a crossbill and a counterclaim that the original professional corporation had been formed only as a convenience to obtain certain tax and other benefits, but that the law practice had been conducted as a

\footnotetext{
${ }^{54} 679$ S2d 637, 639 (Ala 1996).

${ }^{55}$ Id at 639-40.

${ }^{56} 244$ Va 418, 422 SE2d 784, 785 (1992).
} 
partnership-both before and after the corporation's formation. They asked that the court order an accounting of the original firm in accordance with partnership law. In response, the original firm argued that it was a "legal impossibility for a partnership and a corporation to coexist under the circumstances. ${ }^{\text {"57 }}$ The trial court concluded that, while the firm had been "a de jure professional law corporation," it had been conducted as a partnership and should be subject to partnership law. ${ }^{58}$

The Supreme Court of Virginia affirmed the trial court. It held that the practices followed by the professional corporation throughout its existence estopped its members from denying the existence of the partnership. ${ }^{59}$ The professional corporation was a close corporation in which the shareholders conducted the internal affairs of the law practice as a partnership. Thus, the trial court properly settled their rights and liabilities according to partnership law. ${ }^{60}$

B. Minority View: Application of Corporate Law to AttorneyShareholder Withdrawals

1. Applying corporate law in allocating the unfinished business of a professional corporation.

One court has applied corporate law to allocate the unfinished business of a professional corporation upon an attorneyshareholder withdrawal. This holding was based on considerations of statutory interpretation and corporate structure. In Langhoff $I,{ }^{61}$ Langhoff left the professional association of Marr, Langhoff, and Bennett, P.A. ("ML\&B"), which was officially dissolved soon thereafter. The successor corporation, Marr P.C., filed suit to recover fees Langhoff earned subsequent to his departure from a case that had been part of ML\&B's business at the time of his departure. ${ }^{62}$ The trial court applied partnership law and found that Langhoff had breached his fiduciary duty to ML\&B. Because of this breach, he was required to give Marr the fee he had received. ${ }^{63}$ This fee was deemed an asset of the profes-

\footnotetext{
${ }^{57}$ Id (internal quotation marks omitted).

${ }^{58} \mathrm{Id}$.

${ }^{59}$ Id at 788.

${ }^{60}$ Id at 790.

${ }^{61} 81$ Md App 438, 568 A2d 844, 845 (Md Ct Spec App 1990). Langhoffs withdrawal was therefore not concurrent with the dissolution of the professional corporation.

[2. Id.

๗Id at 848 . The court considered Fox persuasive authority and offered the familiar policy arguments: application of partnership law would reduce litigation, strengthen client choice by reducing the profit motive, and maintain consistency in rules across organ-
} 
sional association, to be divided pro rata among the shareholders. ${ }^{64}$

The Court of Special Appeals of Maryland vacated the lower court's holding. The court held that a professional service corporation is a specific type of corporation, and where the state's Professional Service Corporation Act is silent, general corporate law should apply. ${ }^{65}$ The court also pointed to the fact that a professional corporation exists in perpetuity until dissolved in accordance with corporate law. ${ }^{66}$ Finally, the court reasoned that the application of partnership law to a professional service corporation would create an anomalous situation in which there are two forms of legal partnerships-traditional partnerships and professional service corporations-but only one is able to take advantage of corporate tax benefits. ${ }^{67}$ The application of partnership law would also create inconsistencies because corporate principles would apply to resolve stock repurchases and continuity of operations, but partnership law would control asset distribution. ${ }^{68}$ After deciding that corporate law should apply, the court remanded the case to the lower court. ${ }^{69}$

2. Applying corporate law in other contexts to settle the rights and responsibilities of attorney-shareholders in professional corporations.

In other contexts, many courts apply corporate law to settle the rights and responsibilities of a withdrawing attorneyshareholder. These cases provide insight into courts' application of corporate law to professional corporations.

In Melby $v \mathrm{O}^{\prime} \mathrm{Melia},{ }^{70}$ an attorney-shareholder withdrew from a Wisconsin professional service corporation. The founders of the

\footnotetext{
izational forms. Id at 849-50.

${ }^{64}$ Id at 850.

${ }^{65}$ Id at 852.

${ }^{66}$ Id at 852-53.

"7 Id at 855. Applying partnership law in this context essentially makes the professional corporation a partnership except for tax purposes.

Id at 855.

${ }^{6}$ In its discussion of previous cases involving similar issues, the court suggested what corporate law entailed. Id at 853-54. On remand, however, the court of appeals found that an oral agreement between the parties effected an immediate termination of the firm and precluded the need to reach the issue of whether partnership or corporate law applied. In lengthy dicta, however, the court suggested that partnership law applied. Michael E. Marr, PC v Langhoff, 322 Md 657, 589 A2d 470, 475-78 (1991) ("Langhoff I"). In a later case, the Court of Special Appeals declared that its conclusion in Langhoff $I$ remains persuasive dicta. First American Bank of Maryland $v$ Shivers, 97 Md App 405, 629 A2d 1334, 1341 n 5 (Md Ct Spec App 1993).

${ }^{70} 93$ Wis $2 d$ 51, 286 NW2d 373, 373 (Wis Ct App 1979).
} 
corporation had made no provisions in their bylaws or articles of incorporation for acquiring the shares of a withdrawing shareholder. The departing attorney sought an accounting and dissolution of the service corporation according to partnership standards. The trial court denied his request, holding that the case should be decided under corporate standards. ${ }^{71}$

The Court of Appeals of Wisconsin upheld the trial court. The appellate court gave three reasons for its holding. First, limitations on service corporations are not designed to protect the shareholders in their relationships with one another, but to protect individual clients or the general public. ${ }^{72}$ Second, in the absence of specific authority to the contrary, corporate standards should apply as a default rule when a shareholder withdraws from a service corporation..$^{73}$ Finally, a service corporation exists in perpetuity until dissolved in accordance with state corporation law. ${ }^{74}$ The court, however, did not decide what remedy corporate standards provided to the withdrawing attorney-shareholder. ${ }^{75}$

A subsequent case elaborated on the Melby court's reasoning. In Corlett, Killian, Hardeman, McIntosh and Levi, PA v Merritt, ${ }^{76}$ three minority attorney-shareholders left a professional service corporation. These attorneys were unable to resolve amicably their claim that the successor corporation ought to redeem their shares. Thus, they sued for compelled redemption of their shares. ${ }^{77}$ The trial court found in favor of the departing attorneys.

71 Id.

I2 Id at 374.

73 Id.

Id.

${ }^{75}$ The withdrawing attorney-shareholder is probably out of luck. See note 19; Corlett, Killian, Hardeman, McIntosh and Levi, PA v Merritt, 478 S2d 828, 831 (Fla Dist Ct App 1985) ("Absent such a provision for redemption, courts will not write such an agreement for the parties."). However, the Court stated in dictum that:

Attorneys are in a unique situation because their profession is governed by specific ethical standards, and we cannot say that in all situations a service corporation composed of lawyers will be treated like a regular business corporation. The legislature ... provided a manner of sale and purchase of shares of a service corporation when the owner of those shares became disqualified to practice. . . . Ethical considerations may require, when one member of [a] service corporation voluntarily leaves that service corporation, that he be compensated for his shares in the service corporation at a fair value.

Melby, 286 NW2d at 375.

"6 478 S2d 828, 829 (Fla Dist Ct App 1985).

"Id. The court also noted that the departing shareholders claimed an interest in certain contingent fee cases for work performed before their departure. The corporation counterclaimed for moneys collected, after departure, by the shareholders for fees earned by the corporation before their departure. Id at $829 \mathrm{n} \mathrm{2.} \mathrm{These} \mathrm{claims} \mathrm{were} \mathrm{for} \mathrm{quantum}$ meruit-an implicit acknowledgment by the parties that there was no winding up and division of fees pro rata as partnership law would require. 
It ruled that the professional corporation was required to redeem their shares at fair or book value as of the date of departure. ${ }^{78}$ The District Court of Appeal of Florida reversed, holding that a court could not compel a professional service corporation engaged in the practice of law to redeem the shares held by minority shareholders who voluntarily resigned. The court would not order a redemption unless a statute, the articles of incorporation, or an agreement between the parties provided for such a redemption. ${ }^{79}$ The court declared that although this result might be inequitable, it provided an incentive for future parties to contract in advance for the redemption of shares upon withdrawal. When confronted with this same issue, other courts have reached similar results..$^{80}$

\section{THE COURTS' IMPLICIT CATEgORIZATION OF WITHDRAWALS}

Decisions about whether to apply partnership or corporate law to an attorney-shareholder withdrawal from a professional corporation appear arbitrary at first glance. Upon closer inspection, however, the cases demonstrate a clear pattern. Courts implicitly conduct a two-tiered analysis. First, they apply a "continuation of existence" test to determine whether the attorney withdrawal is simultaneous with the dissolution of the professional corporation or whether the professional corporation continues to exist following the withdrawal. ${ }^{81}$ If the withdrawal is in

${ }^{78}$ Id at 829.

${ }^{79}$ Id at 831-34. The court based its decision on the principle that courts should not write an agreement for the parties. Id at 831 . Nevertheless, the court left open the possibility of court-ordered dissolution where there is a deadlock or threat of discontinued corporate business due to evenly divided ownership interests. Id at 832 . This holding is clearly a corporate law solution. See note 19.

${ }^{80}$ See Trittipo v O'Brien, $204 \mathrm{Ml}$ App 3d 662, 561 NE2d 1201, 1208 (1990) (holding that departing attorney-shareholder was not entitled to compelled redemption of shares); Berrett $v$ Purser \& Edwards, 876 P2d 367, 371 (Utah 1994) (same). But see Vinall, 651 P2d at 852 (arguing that equitable and ethical reasons mandate redemption of a departing shareholder's shares).

${ }^{81}$ Fox did not limit its holding to professional corporations that dissolve. However, the majority of courts that consider that case persuasive authority seem to impose this limitation implicitly. See Rothman, 24 Cal Rptr 2d at 571-72; Sufrin, 896 F Supp at 769. In doing so, these courts are actually more faithful to the holding in Jewel than that in Fox. The Fox court overlooked the fact that the law partnership in Jewel was dissolved by mutual agreement of its partners before any disputes arose while the law corporation in $F o x$ was never officially dissolved. In Fox, the law corporation continued to exist under a different name following the withdrawals. 210 Cal Rptr at 262.

The Fox court defended its decision by declaring that "[t]he law should simply recognize that the lawyers once practiced together and are now practicing separately on the same cases as before, and no good purpose is served by characterizing one entity as the members who left and the other entity as the members who remained." 210 Cal Rptr at 265. One commentator has read this sentence to imply that it is irrelevant whether the 
the former category, courts apply partnership law. If it is in the latter category, courts apply corporate law. If courts find that this first tier inquiry is not dispositive, they will sometimes use a second test in which they analyze the extenuating circumstances of the withdrawal in order to determine whether partnership or corporate law should apply. This is a "totality of the circumstances" test.

\section{A. The Continuation of Existence Test}

Courts have applied partnership law in two situations: first, when it is clear that the attorney-shareholders have dissolved the professional corporation, as in Rothman ${ }^{82}$ and Sufrin; ${ }^{83}$ second, when the shareholders have manifested an intention to dissolve the professional corporation but have failed, as in Sullivan $I^{84}$ to comply with the formal requirements of dissolution. Application of partnership law, insofar as it requires the shareholders of a defunct professional corporation to wind up its unfinished business, makes good legal sense for two reasons. First, when the professional corporation is dissolved, there is no longer any inconsistency between the partnership solution and the professional corporation's continued existence. In fact, the dissolution and windup provisions of partnership law are particularly appropriate when the equivalent of an attorney withdrawal from a law partnership has occurred. ${ }^{85}$ Second, when a corporation is dissolved, its assets must be distributed to its shareholders. Ongoing cases are considered part of a professional corporation's assets. ${ }^{86}$ Therefore, in the absence of a previous agreement between the shareholders, dividing the fees from ongoing business on a pro rata basis is the most straightforward and most equitable solution.

firm dissolves completely and that the Jewel xule applies to a "partial dissolution." Anthony L. Marks, Comment, Barefoot Shoemakers: An Uncompromising Approach to Policing the Morals of the Marketplace When Law Firms Split Up, 19 Ariz St L J 509, 527 n 134 (1987). This application of Jewel, however, makes little sense. See Part III.A.

24 Cal Rptr 2d at 573.

896 F Supp at 767.

84 820 P2d at 1251.

${ }^{85}$ The Model Business Corporation Act provides for a windup period of unfinished business following dissolution of a corporation. See Model Bus Corp Act $\$ 14.05$ (a) (cited in note 34 ).

${ }^{86}$ See DelCasino $v$ Koeppel, 207 AD2d 374, 615 NYS2d 454, 455 (NY App Div 1994) (holding that pending contingency fee cases are corporate assets subject to distribution upon dissolution); Rothman, 24 Cal Rptr $2 \mathrm{~d}$ at 573 (holding that unfinished business consists of all matters in progress that have not been completed at the time the professional corporation is dissolved). 
Conversely, courts apply corporate law when the professional corporation has continued to exist after the withdrawal of the attorney-shareholders, as in Langhoff $I,{ }^{87} \mathrm{Melby},{ }^{88}$ Corlett, ${ }^{89}$ Trittipo, ${ }^{90}$ and Berrett. ${ }^{91}$ This rule makes good legal sense. Where a professional corporation has retained its corporate form, a court-ordered dissolution and accounting is reserved for the extreme cases such as a shareholder deadlock or the commission of oppressive acts by majority shareholders. ${ }^{92}$ Application of corporate law is also the more efficient solution..$^{93}$ Forcing professional corporations to undergo a dissolution and winding-up period every time an attorney leaves would be extremely burdensome given the frequency with which attorneys move from firm to firm. It would also be inconsistent with the professional corporation's continuity of life.

\section{B. The Totality of the Circumstances Test}

If courts did not progress beyond the first tier of analysis, they would reflexively apply corporate law to all cases in which a professional corporation continues to exist after an attorneyshareholder withdraws. The decision by the Court of Special Appeals of Maryland in Langhoff $I$, however, does not always apply in these cases. In Langhoff I, the court relied on statutory language and corporate structure in finding that corporate law should apply to allocate fees from unfinished business upon an attorney-shareholder withdrawal. Some courts instead apply partnership law to these cases. This suggests that they are examining the totality of the circumstances in deciding what law to apply following the initial categorization of the withdrawal as not concurrent with the dissolution of the professional corporation. ${ }^{94}$ Of these extenuating circumstances, two worth noting are the breach of fiduciary duty and the "partial dissolution."

At least one court has applied partnership law to the withdrawal of an attorney-shareholder who breached his fiduciary

568 A2d at 855 .

${ }^{88} 286$ NW2d at 374 .

478 S2d at 829.

${ }^{90} 561$ NE2d at 1204-05.

${ }^{91} 876 \mathrm{P} 2 \mathrm{~d}$ at 370.

${ }^{92}$ See note 19.

${ }^{23}$ This Comment assumes that corporate law in these situations extinguishes any fiduciary duties of the withdrawing attorney-shareholder upon termination of his employment. See text accompanying note 18.

No court has examined the totality of the circumstances after finding that the professional corporation has dissolved and that partnership law is appropriate. 
duty to a non-dissolving professional corporation. In Vowell, ${ }^{95}$ one attorney-shareholder and two associates left the professional association in which they practiced law. The court found that the withdrawing shareholder had breached his fiduciary duty to the professional corporation by contacting firm clients to discuss their future representation. ${ }^{96}$ The court, applying partnership law, held that the withdrawing shareholder must account for the fees from cases he took from the firm. ${ }^{97}$ Although the court used a partnership law rationale for its decision, it was not applying the unfinished business rule. Instead, it was punishing the withdrawing attorney for his breach of fiduciary duty to the professional corporation that had occurred before, rather than after, his withdrawal. ${ }^{98}$ Pictured in this light, this case is reconcilable with the general rule that corporate law should apply to attorney withdrawals from non-dissolving professional corporations.

Some courts apply partnership law to withdrawals from a professional corporation where the professional corporation has not officially dissolved, but where the withdrawals have significantly changed the firm's composition from its pre-withdrawal state. ${ }^{99}$ These withdrawals occupy a middle ground between the complete dissolution of the professional corporation and the de minimis withdrawal. Accordingly, they may be thought of as partial dissolutions. ${ }^{100}$ In Fox, for example, three attorneyshareholders and an associate left the professional corporation in which they practiced law. ${ }^{101}$ The shareholders did not dissolve the

956 S2d at 639.

${ }^{96}$ Id.

In Id at 640 .

96 This argument is consistent with the Langhoff $I$ court's suggestion in dicta that, under corporate law, a withdrawing shareholder might have to account for the fees from cases he took from the professional corporation if he owed a fiduciary duty to it through his status as an officer, director, or stockholder. See Langhoff I, 568 A2d at 856.

${ }^{99}$ Courts may be applying partnership law in this situation because they believe that the change is significant enough that the successor corporation is totally different from the original corporation. Alternatively, they may be applying partnership law because they believe that equity requires it.

${ }^{100}$ The case law demonstrates that courts have not quantified the change in composition necessary for a finding of what this Comment terms "partial dissolution." In Corlett, where the court applied corporate law, the three withdrawing shareholders owned a combined 29.5 percent interest in the corporation. $478 \mathrm{~S} 2 \mathrm{~d}$ at 832 . In Langhoff I, where the court also applied corporate law, the withdrawing shareholder owned a 37.5 percent interest in the corporation. $568 \mathrm{A2d}$ at 845 . In Fox, where the court applied partnership law, the three withdrawing shareholders together owned a 56.25 percent interest in the corporation. $210 \mathrm{Cal}$ Rptr at $262 \mathrm{n}$ 1. In Boyd, where the court applied partnership law, the four withdrawing shareholders together owned a 40 percent interest in the corporation. $422 \mathrm{SE2d}$ at 786. Absent clear standards in this area, courts have relative freedom to find a justification for the application of partnership law.

${ }^{101} 210$ Cal Rptr at 262. 
professional corporation, and it continued to exist under a different name. ${ }^{102}$ The court nonetheless applied partnership law to settle the unfinished business of the professional corporation. ${ }^{103}$

To support their finding of "partial dissolution," courts often appeal to partnership aspects of the professional corporation. The fact pattern in Boyd was similar to that in Fox: four attorneyshareholders left the professional corporation in which they practiced law, leaving one attorney-shareholder behind; the attorneyshareholders did not dissolve the original professional corporation. ${ }^{104}$ After finding that these attorneys had acted like partners in many respects, the court in Boyd applied partnership law to settle the rights and responsibilities of the attorneys. ${ }^{105}$ However, many professional corporations experience significant turnover and many attorneys practicing in these corporations act like partners. Taken together, the approaches in Fox and Boyd suggest that courts have significant freedom to apply partnership law to attorney-shareholder withdrawals.

\section{A PROPOSAL FOR A BRIGHT LINE STANDARD OF CATEGORIZATION}

\section{A. Problems with the Current Approaches}

1. Failure to give notice to the parties involved.

This Comment has argued that courts' categorization of attorney-shareholder withdrawal cases under the "continuation of existence test" makes sense. One problem with the categorization process, however, is that courts have been making the categorization determination implicitly, not explicitly. This contradicts the fundamental concept of notice in the law, which requires that individuals know the law in advance in order to foresee its impact on their rights and responsibilities. ${ }^{106}$ Courts should therefore explicitly acknowledge the continuation of existence test and explicitly explain how they are categorizing the withdrawal in the case before them. This will provide attorneys in a professional corporation with a rough idea of whether partnership law

${ }^{102} \mathrm{Id}$.

${ }^{103}$ Fox, 210 Cal Rptr at 265.

${ }^{104}$ Boyd, 422 SE2d at 785.

${ }^{105} \mathrm{Id}$ at 790.

${ }^{106}$ See, for example, Richard A. Posner, Economic Analysis of Law $\$ 8.4$ at 265 (Little, Brown 4th ed 1992) (arguing that law must be public if it is to serve its deterrence function). 
or corporate law will apply when an attorney withdraws from the corporation.

Explicitly recognizing the categorization will have a profound effect on the behavior of the parties involved. Not only will the attorney-shareholders know what law they are subject to, they will also be able to affect what law the courts apply. If attorney-shareholders desire to be treated under partnership law, they will make an agreement to dissolve the professional corporation in conjunction with an attorney withdrawal. On the other hand, if they desire corporate law treatment, they will not make such an agreement.

2. The problem with the ad hoc "totality of the circumstances" test.

The second tier of the categorization process creates havoc within the law of shareholder withdrawal. This Comment has asserted that courts sometimes resort to an ad hoc factfinding approach. Under this approach, they examine the extenuating circumstances to determine whether to apply partnership law or corporate law. This method does not lead to optimal results. Cases like Fox and Boyd are particularly troubling. In these cases, the courts applied partnership law after determining that the professional corporation had undergone a "partial dissolution." First, these holdings are most likely a misapplication of partnership case law. ${ }^{107}$ Second, this analysis requires an imprecise measurement of a number of factors, including whether the change in the professional corporation's composition is significant and whether the professional corporation has acted more like a partnership than a corporation. This uncertainty presents a second serious problem of notice to the parties. There is no clear line between a withdrawal and a "partial dissolution," one clarifying when a professional corporation looks more like a partnership than a corporation. ${ }^{109}$ Different courts will weigh

\footnotetext{
${ }^{100}$ See note 81.

${ }^{108}$ See note 100.

${ }^{109}$ The courts occasionally find that a "de facto" or "implied" partnership exists where lawyers take the corporate form but act as partners. See, for example, Boyd, $422 \mathrm{SE2d}$ at 790. Although case law is unsettled on what factors create an apparent partnership, "[m] ost court decisions have focused on whether the attorneys have given the client reason to believe that representation was being provided by a partnership." Ronald E. MalIen and Sheila M. Lamb, The Liability of Partnerships and Professional Corporations, 2 Legal Malpractice Rep 9, 10 (1990). It is not clear why the client's perspective should affect the type of law that governs relations between the attorneys. See also Kelvin $\mathrm{H}$. Dickinson, Partners in a Corporate Cloak: The Emergence and Legitimacy of the Incorporated Partnership, 33 Am U L Rev 559, 579-82 (1984) (listing factors courts will consider
} 
these circumstances differently, precluding a uniform application of the law and preventing the parties from being able to anticipate a court's actions.

This approach also places courts in a difficult position. First, courts must expend valuable judicial resources in factfinding. Second, judges are not business experts. ${ }^{110}$ It may be difficult, when given poorly defined standards and no definitive policy rationale, for these judges to determine what constitutes "significant change" for a professional corporation or whether a professional corporation has functioned more like a partnership or a corporation. ${ }^{111}$ Even if courts do possess the requisite technical expertise, case law suggests that a governmental body cannot arbitrarily label a professional corporation a partnership. ${ }^{112}$ This logic would seem to apply to courts deciding attorney withdrawal cases.

\section{B. Proposed Application of Partnership Law Only to Dissolution of Professional Corporations}

Given the notice, judicial economy, and expertise problems associated with the totality of circumstances test, courts should abandon it entirely. In its place, courts should rely solely on the continuation of existence test. This test is a bright line rule that applies partnership law to attorney-shareholder withdrawals where there is clear evidence of an agreement or an intention to dissolve the corporation. Corporate law should apply in all other circumstances. This new standard will benefit both the parties

when determining whether a business venture is a partnership).

Conversely, individuals who take advantage of practicing in a corporate form will be estopped from denying the existence of the corporation. See Early Detection Center, Inc $v$ Wilson, 248 Kan 869, 811 P2d 860, 866 (1991) (describing doctrine of corporation by estoppel); Shapoff $v$ Scull, 222 Cal App 3d 1457, 272 Cal Rptr 480, 486-87 (1990) (same); Jones $v$ Teilborg, 151 Ariz 240, 727 P2d 18, 25 (Ariz Ct App 1986) (applying doctrine of corporation by estoppel). In many cases, the factual circumstances simultaneously support a finding that the professional corporation was treated as a partnership and a finding that it was treated like a corporation.

${ }^{110}$ See Dodge v Ford Motor Co, 204 Mich 459, 170 NW 668, 684 (1919).

${ }^{111}$ This inquiry might be incorrect altogether. Maybe courts should ask what the parties would have contracted for had transaction costs been zero, not whether the professional corporation is more like a partnership than a publicly held corporation. See Easterbrook and Fischel, The Economic Structure of Corporate Law at 250 (cited in note 19). Assuming that the parties were not ignorant of the structure of the professional corporation, it is reasonable to conclude that where the corporation has not been dissolved, they would have wanted corporate law treatment.

${ }^{112}$ See Kurzner $v$ United States, 413 F2d 97, 111 (5th Cir 1969) (finding arbitrary and discriminatory the IRS Commissioner's decision to treat validly incorporated professional service organizations as partnerships for federal income tax purposes if they more closely resemble partnerships than corporations). 
involved and the courts. The parties will know when partnership law applies and when corporate law applies. With this knowledge, they will be able to adjust their behavior accordingly. ${ }^{113}$ Furthermore, courts will have clear guidance in determining whether to apply partnership or corporate law. ${ }^{114}$

In applying corporate law to attorney-shareholder withdrawals that are not concurrent with the dissolution of the professional corporation, courts should apply the principles that govern closely held corporations. A closely held corporation is a special corporate form that includes some or all of the following factors: a limited number of shareholders; limited or nonexistent trading of the corporation's shares; and a significant level of shareholder involvement in the management of the corporation. The attorneys in a professional corporation resemble shareholders in a closely held corporation much more than they resemble shareholders in a publicly held corporation. ${ }^{115}$ Like the owners of a closely held corporation, the attorney-shareholders in a professional corporation are of a limited number and are heavily involved in managing the corporation. Furthermore, public trading is nonexistent. This similarity between closely held and professional corporations has two ramifications for the proposed rule. First, because the rule does not require that a professional corporation repurchase a withdrawing attorney's shares, ${ }^{116}$ attorneys should contract for such a provision in advance. Second, shareholders in a close corporation owe each other fiduciary duties of loyalty and good faith. The level of these fiduciary duties may approach that of the fiduciary duties of partners. ${ }^{117}$ By applying

\footnotetext{
${ }^{123}$ Because the rule does not eliminate court factfinding entirely, see note 114 , it is vulnerable to the objection that it does not provide sufficient notice to the parties. There are at least two responses to this objection. First, this rule greatly improves the totality of the circumstances test, which requires parties to guess whether they would receive partnership or corporate law treatment depending on the share ownership percentage of withdrawing attorney-shareholders. Second, it should be fairly clear to both the parties and the courts when the parties have agreed to dissolve the professional corporationthis inquiry into objective intent is omnipresent in contract law.

"II Clear guidance does not mean the absence of any factfinding responsibilities. A court might have to determine whether the parties really intended to dissolve the professional corporation. See text accompanying notes $48-49$. In addition, once a court determines which law to apply, it may have to determine whether the departing attorneyshareholder violated his fiduciary duties. See Langhoff I, 568 A2d at 855-56. See also Part IV.D.1.

${ }^{115}$ See Marks, Comment, 19 Ariz St L J at 537 n 206 (cited in note 81). See also Model Stat Close Corp Supp § 2(b) (cited in note 33) ("This Supplement applies to a professional corporation organized under the [Model] Professional Corporation Supplement.... .").

${ }^{116}$ See text accompanying note 19.

${ }^{117}$ See Donahue v Rodd Electrotype Co, 367 Mass 578, 328 NE2d 505, 515 (1975) ("Because of the fundamental resemblance ... we hold that stockholders in the close corporation owe one another substantially the same fiduciary duty in the operation of the enter-
} 
the duties of close corporations to attorney-shareholders, courts can impose a powerful limitation on the freedom of attorneys to withdraw indiscriminately from a professional corporation and to take its business with them. ${ }^{118}$

\section{Justifications for the Bright Line Standard}

1. Legal justifications: considerations of statutory language and the structure of the professional corporation.

The proposed bright line rule is much more faithful to state corporation statutes and to the structure of professional corporations than the two tier process. Most state professional corporation statutes provide that where the professional corporation act is silent, the state's business corporation law applies unless inconsistent with the provisions of the professional corporation law. ${ }^{119}$ Under the corporate model, a shareholder's interest in the corporation is terminated upon the sale of his shares. ${ }^{120}$ The application of partnership law principles of dissolution and windup upon a withdrawal from a non-dissolving professional corporation requires the withdrawing attorney-shareholder to maintain an interest in the corporation. It therefore directly contradicts the state statutes that contain this provision.

Even if the statute establishing the professional corporation does not explicitly mandate corporate law as a default rule, when the corporation continues to exist after the withdrawal, the application of corporate law is more faithful to the structure of the professional corporation. The principles of partnership law are inconsistent with the professional corporation's continuity of life. In order to apply these principles faithfully, a court would be required to dissolve the corporation, a task it is generally unwilling to do. ${ }^{121}$ However, neither this structural problem nor the aforementioned state statutory language is relevant once the professional corporation has officially dissolved. In that situation,

prise that partners owe to one another."); Harry G. Henn and John R. Alexander, Law of Corporations and Other Business Enterprises $§ \$ 235,268$ (West 3d ed 1983) (discussing similarities between partnerships and close corporations).

${ }^{118}$ Once again, the factfinding inherent in this inquiry conflicts with the need for notice. However, courts are very experienced in determining breaches of fiduciary duty in corporate law cases. See Part IV.D.1.

${ }^{119}$ Hillman, Lawyer Mobility § 6.7.2 at 6:30 (cited in note 1). See also Model Stat Close Corp Supp \& 2(a) (cited in note 33) ("The [Model] Business Corporation Act applies to statutory close corporations to the extent not inconsistent with the provisions of this Supplement.").

${ }^{20}$ See text accompanying note 16.

${ }^{121}$ See note 19. 
partnership law serves as a convenient way for the court to distribute the assets of a professional corporation.

2. Policy justifications: avoiding the inequities of partnership law and inconsistent treatment of the professional corporation.

The proposed bright line rule makes better sense from a policy standpoint as well. First, the bright line rule reduces the inequities that occur when partnership law is applied to a corporation that continues to exist. In some of these situations, application of the no-compensation rule may deny an attorney the benefits of his or her labor while allowing a windfall to fellow shareholders who had a relatively light burden during the windup phase. ${ }^{122}$ Seen in this light, the no-compensation rule may promote dissolution by encouraging shareholders to "grab and leave" when their wind-up duties would be light relative to those of their fellow shareholders. ${ }^{123}$

The no-compensation rule also creates the problems of "lock out" and "lock in." ${ }^{\text {"124 }}$ By forcing the partners to reallocate cases in an equitable manner and by not allowing compensation for work performed, the no-compensation rule may "lock out" the client from retaining his chosen attorney, who has little incentive to continue working on the case. ${ }^{125}$ Conversely, the no-compensation rule may "lock in" dissatisfied shareholders into the professional corporation by forcing them to remain together because the windup burdens would be sufficiently large to render dissolution infeasible. ${ }^{226}$

Under the bright line rule this Comment has proposed, partnership law would apply only after the shareholders decided to dissolve the professional corporation. Given that this decision must be made through formal procedures rather than unilaterally by one shareholder, the proposed rule will minimize the concern of the impact of partnership law principles on the decision to dissolve.

The bright line rule also avoids the problem identified in Langhoff I: that "consistency" in treatment across organizational forms might lead to absurd results. The application of partner-

\footnotetext{
${ }^{122}$ Weinstein, 33 Duquesne L Rev at 873 (cited in note 6).

${ }^{203} \mathrm{Id}$.

${ }^{124}$ For hypothetical examples of lock out and lock in, see Mark H. Epstein and Brandon Wisoff, Comment, Winding Up Dissolved Law Partnerships: The No-Compensation Rule and Client Choice, 73 Cal L Rev 1597, 1615-19 (1985).

${ }^{205}$ Weinstein, 33 Duquesne L Rev at 874-75 (cited in note 6).

${ }^{126}$ Id at 875.
} 
ship law to professional corporations would effectively create two tiers of partnerships, with only one receiving favorable tax treatment. Given that the tax benefits of incorporation are almost nonexistent today, applying partnership law would render professional corporation statutes partially superfluous. ${ }^{127}$ In addition, applying partnership law would also divide professional corporation functions into two tiers: stock repurchases and continuity of operations would receive corporate treatment, but asset distribution would receive partnership treatment. ${ }^{128}$ Once the professional corporation is dissolved, however, there is no lack of uniformity. At that time, the professional corporation has ceased to exist and the only concern is how its assets are to be distributed.

\section{Potential Problems with the Bright Line Standard} leaving."

1. The problem of an attorney-shareholder "grabbing and

One problem that courts frequently cite in defending the partnership law model is that of "grabbing and leaving." 29 If attorney-shareholders are not obliged to share fees on a pro rata basis from cases they remove from the professional corporation, they will have every incentive to grab lucrative clients and leave the firm. The possibility of grabbing and leaving is particularly acute under the proposed bright line rule, because withdrawing attorney-shareholders would be free to compete with their former firm if it continues to exist. However, courts can mitigate this potential problem by aggressively enforcing the two loyalties owed by withdrawing attorney-shareholders: their fiduciary duty to the professional corporation, and their fiduciary duty to their clients.

First, courts can police withdrawals to ensure that the withdrawing attorney-shareholder did not breach his fiduciary duty as an officer, director, or shareholder of the firm. ${ }^{130}$ In this context, the contours of fiduciary duty are derived from the principles of agency. ${ }^{131}$ An attorney-shareholder is an agent of the pro-

\footnotetext{
${ }^{2 m}$ See note 25.

${ }^{22}$ See text accompanying notes 61-68.

${ }^{22}$ See, for example, Fox, 210 Cal Rptr at 265.

${ }^{130}$ See text accompanying notes 95-98. Another cause of action a law firm might bring against departing attorney-shareholders who take firm clients with them is the common law tort of intentional interference with contract. See Mark D. Flanagan, Comment, Lateral Moves and the Quest for Clients: Tort Liability of Departing Attorneys for Taking Firm Clients, 75 Cal L Rev 1809, 1810-11 (1987).

${ }^{131}$ See Restatement (Second) of Agency §§ 387-96 (1958).
} 
fessional corporation by virtue of being a shareholder, ${ }^{132}$ and is an agent of the law firm generally, regardless of its form. ${ }^{133}$ In matters concerning the firm's business, an attorney must act solely for the benefit of the firm. ${ }^{134}$ An attorney must also make full disclosures to other members of the firm about matters affecting the firm's business. ${ }^{135}$ Most significantly, an attorney is forbidden from competing with the firm while he remains in its employment, ${ }^{136}$ although he may compete with it after termination of the employment relationship. ${ }^{137}$ In determining whether an attorney has breached a fiduciary duty to his law firm, courts have followed this before-after distinction and have construed "compete" to mean the solicitation of firm clients or employees without the firm's knowledge while still in the employment of the firm. ${ }^{138} \mathrm{Ab}$ sent such activity, courts have found that the departing attorneyshareholder has not breached his fiduciary duty. ${ }^{139}$

${ }^{122}$ See text accompanying notes 117-18.

${ }^{133}$ Peter R. Jarvis and Tracy J. White, Civil Liability Aspects of Lawyers Leaving Law Firms, 1993 Prof Law 54, 54 (1993 Symposium); Marks, Comment, 19 Ariz St L J at 53738 (cited in note 81 ).

${ }^{134}$ See Restatement (Second) of Agency $\$ 387$ (cited in note 131).

${ }^{135}$ See Dowd and Dowd, Ltd v Gleason, 284 Ill App 3d 915, 672 NE2d 854, 862 (1996); Meehan v Shaughnessy, 404 Mass 419, 535 NE2d 1255, 1264 (1989); Bray v Squires, 702 SW2d 266, 270 (Tex Ct App 1985).

${ }^{136}$ "Unless otherwise agreed, an agent is subject to a duty not to compete with the principal concerning the subject matter of his agency." Restatement (Second) of Agency $\$ 393$ (cited in note 131).

${ }^{137}$ "After the termination of his agency, in the absence of a restrictive agreement, the agent can properly compete with his principal as to matters for which he has been employed. . . . Even before the termination of the agency, he is entitled to make arrangements to compete, except that he cannot properly use confidential information peculiar to his employer's business and acquired therein. . . . He is not, however, entitled to solicit customers for such rival business before the end of his employment nor can he properiy do other similar acts in direct competition with the employer's business." Restatement (Second) of Agency $\S 393$, comment e (cited in note 131). This provision tracks the conclusion of the Langhoff I court. See text accompanying note 18.

${ }^{238}$ See, for example, Vowell, 679 S2d at 639 (finding breach of fiduciary duty to professional corporation where departing attorney-shareholder, while still an officer, director, and shareholder of the corporation, contacted and agreed to represent clients of corporation and did not disclose these contacts to other attorneys); Dowd, 672 NE2d at 862-63 (finding that cause of action for breach of fiduciary duty was sufficiently stated where departing members of professional law corporation allegedly failed to inform the corporation that they were going to start their own law firm until their resignations and solicited several corporation employees before resignations). But see Vincent R. Johnson, Solicitation of Law Firm Clients by Departing Partners and Associates: Tort, Fiduciary, and Disciplinary Liability, 50 U Pitt L Rev 1, 102-06 (1988) (arguing that pre-departure negotiation with clients regarding future representation supports client's freedom of choice).

${ }^{139}$ See, for example, Bray, 702 SW2d at 270-71 (holding that associates' preparation to leave law firm to enter into competition is not sufficient to constitute breach of fiduciary duty, absent evidence that they solicited business of the law firm while employed); Meehan, 535 NE2d at 1264 (holding that former partners' secret setting up of new firm during tenure at old firm did not breach fiduciary duty, but unfairly acquiring consent from 
Grabbing and leaving usually results in unjust enrichment for the breaching attorney-shareholder. Such a breach of fiduciary duty should therefore be remedied by returning the parties to the same position they were before the breach. ${ }^{140}$ Applying a partnership solution that forces the breaching attorney to turn the fees received from improperly removed cases over to the firm to be divided among his fellow partners or shareholders on a pro rata basis accomplishes this task, because it is the result that would have occurred had the attorney not left the firm. Recognizing this fact, courts have applied this remedy to improper attorney withdrawals from both professional corporations ${ }^{141}$ and partnerships. ${ }^{142}$

One might be concerned that judicial oversight will undermine the default rule's simplicity and uniformity of application by requiring courts to examine factual circumstances to determine whether a breach of fiduciary duty occurred. The case law demonstrates, however, that the required factfinding is extremely limited; courts need only determine whether the attorney solicited firm clients or employees prior to withdrawal and without disclosure to his fellow attorneys. The administrative costs of such a determination should be relatively small.

In addition, courts can play an especially useful role in regulating "grabbing and leaving" because attorneys cannot easily do so through private contract. Noncompetition clauses are generally discouraged by rules of legal ethics. ${ }^{143}$ Furthermore, courts often strike them down as inconsistent with the public's right to select the attorney of its choice. ${ }^{144}$ Judicial involvement in

clients to remove cases from old firm at same time did).

${ }^{140}$ This remedy is the contract law remedy of restitution. See Restatement (Second) of Contracts § 344 (1981); Dan B. Dobbs, Handbook on the Law of Remedies $\$ 12.1$ at 786 (West 1973).

${ }^{141}$ See Vowell, $679 \mathrm{~S} 2 \mathrm{~d}$ at 640 . The Vowell court allowed the withdrawing attorneyshareholder a "reasonable hourly rate" for the time he spent completing the work on the cases he took from the old firm. Id. This extension of the UPA's allowance for "reasonable overhead expenses" is questionable, because it seems to remain neutral between a breach and nonbreach rather than actively discouraging breaches.

${ }^{12}$ See Meehan, 535 NE2d at 1269-71.

${ }^{1 * 3}$ See Model Rules of Professional Conduct Rule 5.6 (ABA 1995) (providing that "[a] lawyer shall not participate in offering or making: (a) a partnership or employment agreement that restricts the right of a lawyer to practice after termination of the relationship ..."); Model Code of Professional Responsibility DR 2-108 (ABA 1982) (same).

${ }^{14}$ See, for example, Whiteside $v$ Griffis \& Griffis, PC, 902 SW2d 739, 743-44 (Tex Ct App 1995) (holding that provision in stock agreement that withdrawing shareholder could not practice law or compete against the corporation within a radius of three hundred miles for a period of five years void as against Texas Code of Professional Responsibility DR 2-108); Judge v Bartlett, Pontiff, Stewart \& Rhodes PC, 197 AD2d 148, 610 NYS2d 412, 413-14 (NY App Div 1994) (holding that termination of agreement requiring forfeiture of 75 percent of future benefits for competition was void as against New York Code of 
this area should therefore be welcomed by both the courts and the parties involved.

Second, the courts can enforce an attorney's fiduciary duty to his client. The Model Code of Professional Responsibility and the Model Rules of Professional Conduct both provide significant constraints on attorney mobility. On the most basic level, the attorney must act in the best interest of the client. ${ }^{145}$ In addition, disciplinary rules prevent an attorney from taking on a client's representation when he possesses a potential conflict of interest. ${ }^{146}$ Where it would be in the best interest of the client to retain the professional corporation's representation, the combined effect of these rules should greatly minimize the risk of "grabbing and leaving."

2. The problem of an attorney-shareholder owning worthless shares after withdrawal.

If an attorney-shareholder leaves a professional corporation and nothing in the state statutes, the articles of incorporation, or the corporate bylaws provides for an automatic redemption of shares, the attorney may end up holding shares that are valueless because of the lack of a market for them. ${ }^{147}$ The corporation might either refuse to redeem the shares or coerce the departing attorney-shareholder into selling the shares at a discount. Although the shareholder may request that a court dissolve the corporation, that request is unlikely to succeed because courts may well be hesitant to dissolve a profitable corporation. ${ }^{148}$

Professional Responsibility DR 2-108); Spiegel $v$ Thomas, Mann \& Smith, PC, 811 SW2d 528, 529-31 (Tenn 1991) (holding that conditioning deferred compensation on not practicing law violates Disciplinary Rule 2-108 of the Rules of the Tennessee Supreme Court). See generally Hillman, Lawyer Mobility $\$ 2.3 .4$ at 2:45-77 (cited in note 1).

${ }^{145}$ See Model Code of Professional Responsibility EC 5-1 ("The professional judgment of a lawyer should be exercised . . . solely for the benefit of his client."), EC 5-2 ("A lawyer should not accept proferred employment if his personal interests or desires will ... . affect adversely the ... service to be rendered the prospective client."), EC 5-11 ("A lawyer should not permit his personal interests to influence his advice relative to a suggestion by his client that additional counsel be employed.").

${ }^{146}$ See Model Code of Professional Conduct DR 5-101 ("[A] lawyer shall not accept employment if the exercise of his professional judgment on behalf of his client will be . . . affected ... [by] his personal interests."), DR 5-105 ("A lawyer shall decline proferred employment . . . if it would be likely to involve him in representing different interests."), DR 5-107 ("Except with the consent of his client after full disclosure, a lawyer shall not accept legal compensation for his legal services from one other than his client."). See also Model Rules of Professional Responsibility Rule 1.7(b) ("A lawyer shall not represent a client if the representation of that client may be materially limited by the lawyer's responsibilities to another client or to a third party, or by the lawyer's own interests. . . .").

${ }^{117}$ See Part II.B.2.

${ }^{148}$ See note 19. 
While the courts in Vinall and Melby have suggested that courts should order the automatic redemption of shares upon termination of an attorney's employment, ${ }^{149}$ such a solution is unmanageable and also undermines incentives for parties to settle these issues in advance. Automatic redemption does solve the equitable problem created by the illiquidity of professional corporations' shares. ${ }^{150}$ It also avoids the possible ethical problem of a shareholder owning shares in multiple law corporations at the same time. ${ }^{151}$ However, many courts have adopted a better view, rejecting this solution on the principle that courts should defer to the business judgment of the majority shareholders and should refrain from writing a contract for the parties. ${ }^{152}$ Ordering an automatic redemption would also necessarily require the courts to calculate a fair value for the shares, a task that involves complex factfinding for which they may be ill-suited. Given these limitations, courts should not order an automatic redemption of a departing attorney's shares. While the corporate law solution may occasionally be inequitable in these cases, it provides incentives to private parties to contract in advance in order to avoid this inequity. ${ }^{153}$

\section{CONCLUSION}

Courts are frequently called upon to allocate the unfinished business of a professional corporation upon an attorneyshareholder withdrawal. Courts currently base their decision on whether to apply partnership law or corporate law to such a withdrawal upon an implicit categorization of the withdrawal as either a dissolution or non-dissolution of the professional corporation. While this categorization of withdrawals is sensible, courts destroy hopes of a uniform application of the rule by often resorting to factfinding in cases that present extenuating circumstances. In place of this ad hoc approach, courts should use a bright line default rule under which partnership law applies to an attorney withdrawal only where there is clear evidence of dissolution of the professional corporation. Corporate law should be

\footnotetext{
${ }^{19}$ Vinall, 651 P2d at 852; Melby, 286 NW2d at 375.

${ }^{150}$ See Corlett, 478 S2d at 835-36 (Hubbart dissenting); Berrett, 876 P2d at 375-76 (Stewart dissenting).

${ }^{151}$ See Berrett, 876 P2d at 375-76.

${ }^{152}$ See text accompanying notes 76-80. In contrast to the problems pertaining to "grabbing and leaving," attorneys can easily provide for redemption in advance.

${ }^{153}$ For an economic explanation of why automatic buyout rights are undesirable, see Easterbrook and Fischel, The Economic Structure of Corporate Law at 242 (cited in note 19).
} 
applied in all other circumstances. Corporate law under this rule entails terminating an attorney-shareholder's fiduciary duties to complete firm business for the benefit of the continuing attorneyshareholders upon his departure from the professional corporation-regardless of whether he has sold his ownership shares back to the professional corporation.

Such an approach is more faithful to both the statutory language and the structure of the professional corporation than the current approach. Furthermore, its application will benefit both the courts and the relevant parties. Courts will save valuable judicial resources in deciding these cases and the parties will benefit from the notice and predictability of the rule. Given these advantages, both courts and the parties will have an incentive to resolve any problems that might be present under the new rule. Aggressive enforcement of the fiduciary duties of attorneys toward each other and their clients should keep to a minimum the problem of attorneys "grabbing and leaving." Likewise, attorneys in these situations will draft share repurchase agreements in advance to avoid the inequity of an attorney owning worthless shares upon withdrawal. 


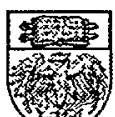

